\title{
Analisis Muatan Pendidikan Karakter Buku Teks IPS SMP di Kota Surakarta
}

\author{
FETTY PERMATASARI DAN DARMIYATI ZUCHDI \\ Universitas Negeri Yogyakarta \\ fettypermata@gmail.com
}

\begin{abstract}
Abstrak
Penelitian ini bertujuan mengungkap: (1) muatan pendidikan karakter yang tersaji dalam materi buku teks IPS SMP di Kota Surakarta, (2) kesesuaian Nilai-nilai karakter yang diintegrasikan dalam buku teks dengan peta nilai untuk siswa SMP berdasarkan bahan pengembangan pendidikan budaya dan karakter bangsa, dan (3) kesesuaian pendekatan pendidikan karakter dalam buku teks dengan pendekatan komprehensif. Penelitian ini merupakan penelitian analisis konten inferensial. Fokus penelitiannya adalah muatan pendidikan karakter pada materi IPS yang disajikan dalam buku teks IPS SMP kelas VII semester 1 di Kota Surakarta. Teknik analisis konten melibatkan tiga orang rater yang dibekali dengan pedoman lembar analisis muatan pendidikan karakter. Hasil penelitian menunjukkan bahwa ketiga buku teks memuat pendidikan karakter berupa Nilai-nilai karakter, yang disajikan secara eksplisit dan implisit. Hasil analisis menunjukkan bahwa muatan pendidikan karakter dalam ketiga buku teks berkategori kurang memadai dengan rerata sebesar $31,33 \%$.
\end{abstract}

Kata kunci: pendidikan karakter, buku teks IPS

\begin{abstract}
This research aims at revealing: (1) the content of character education presented in social studies textbooks for SMP in Surakarta, (2) the suitability of character values integrated in the textbooks with the values category for SMP based on material development of cultural education and nation character, and (3) the suitability of the character education approach in the textbook with comprehensive approach. This research is an inferential content analysis. It focuses on the content of character education of social studies material included in the textbook for the first grade students of SMP in Surakarta. The content analysis involved three raters who were given guidline sheets of items analysis. The findings show that the three textbooks integrate character education in the form of character values which are presented explicitly and implicitly. The result of the analysis indicates that the content of character education in the three textbooks is categorized inadequate with a mean score of $31.33 \%$.
\end{abstract}

Keywords: character education, social studies textbooks 


\section{PENDAHULUAN}

Era globalisasi mempengaruhi pergeseran nilai-nilai moral dan karakter anak. Terlebih hal tersebut diiringi oleh tingkat kemajuan teknologi informatika yang berge rak maju dalam hitungan detik. Alhasil kejadian di belahan dunia yang satu akan dapat langsung diikuti dan diketahui oleh belahan dunia lainnya dengan begitu cepat. Pada kondisi inilah anak globalisasi hidup dan menjadi tahu segalanya. Akibatnya, anakanak mulai mengabalkan Nilai-nilai moral.

Teladan para birokrat dan elite politik terasa demikian kurang. Perilaku yang me reka pertunjukkan di depan mata anakanak bangsa banyak menerabas Nilai-nilai mo ral. Tak ayal, hal itu berpengaruh pada anak dalam hal ini pelajar, untuk bertindak tidak sesuai tuntunan moral. Sebutlah banyak pelajar yang tidak punya sopan santun, suka tawuran, senang pornografi, memiliki hobi narkotika dan minum minuman keras, mencuri, berjudi sampai aborsi. Kenyataan itu menunjukkan bahwa degradasi moral di kalangan pelajar kian parah. Oleh sebab itulah, lantas muncul berbagai alternatif solusi. Dari sekian banyak solusi, penerapan pendidikan karakter dalam pembelajaran di sekolah dianggap menjadi salah satu obat mujarab mengatasi problematika tersebut.

Implementasi pendidikan karakter di sekolah salah satunya dapat dilakukan melalui pengintegrasian pendidikan karakter dalam pembelajaran pada setiap mata pelajaran. Ilmu Pengetahuan Sosial (IPS) sebagai studi terintegrasi dari ilmuilmu sosial untuk mencapai kompetensi kewarganegaraan yang baik dalam rangka mengkritisi isuisu sosial, tentunya menjadi mata pelajaran strategis untuk mengaplikasikan pendidikan karakter. Sementara itu, terkait dengan implementasi kurikulum IPS, bahan ajar yang baik menjadi salah satu bagian penting demi tercapainya pembelajaran IPS yang berkualitas.

Meskipun telah banyak bahan ajar selain cetak, keberadaan bahan ajar cetak khususnya buku teks tetap dianggap memiliki peran strategis dalam kegiatan pembelajaran. Sa yangnya, sejumlah buku teks IPS minim muatan pendidikan karakter. Kondisi tersebut semakin diperparah dengan sedikitnya guru IPS yang mau melakukan kajian isi baik terhadap materi, penyajian, maupun muatan pendidikan karakter dalam buku teks IPS SMP. Padahal, pendidikan karakter bisa dituangkan secara komprehensif dalam buku teks. Seperti diungkapkan Kirschenbaum (1995: 31) bahwa pendekatan komprehensif mencakup empat aspek yakni inkulkasi nilai, keteladanan nilai, fasilitasi nilai, serta pengembangan keterampilan akademik dan sosial. Sementara itu, Nilai-nilai yang dituangkan dalam buku teks bisa disesuaikan dengan materi atau kompetensi dasar.

Nilai-nilai utama yang menjadi target dalam pembelajaran bisa beragam. Dalam buku bahan pelatihan pengembangan pendidikan budaya dan karakter bangsa yang dikeluarkan oleh Pusat Kurikulum Kemdiknas (2010: 910) telah dipetakan sebanyak 18 nilai yang seharusnya bisa diterapkan di jenjang pendidikan dasar dan menengah. Nilai-nilai tersebut bersumber dari agama, Pancasila, budaya dan tujuan pendidikan nasional. Nilai-nilai tersebut yaitu 1) religius, 2) jujur, 3) toleransi, 4) disiplin, 5) kerja keras, 6) kreatif, 7) mandiri, 8) demokratis, 9) rasa ingin tahu, 10) semangat kebangsaan, 11) cinta tanah air, 12) menghargai prestasi, 13) bersahabat/komunikatif, 14) cinta damai, 15) gemar membaca, 16) peduli lingkungan, 17) peduli sosial dan 18) tanggung jawab.

Berdasarkan permasalahan tersebut, kiranya perlu adanya suatu analisis konten (content analysis) untuk mengkaji muatan pendidikan karakter pada sejumlah buku teks IPS SMP yang digunakan di Kota Surakarta ditilik dari peta nilai untuk siswa SMP dalam bahan pelatihan pengembangan pendidikan budaya dan karakter bangsa, serta pendekatan pendidikan karakter komprehensif. Lebih rinci, sesuai dengan keterkaitan nilai, jenjang kelas dan indikator untuk siswa SMP dalam bahan pelatihan pengembangan pendidikan budaya dan karakter bangsa untuk mengkaji muatan pendidikan karakter dalam penelitian ini tidak mengacu secara keseluruhan pada 18 nilai, tetapi hanya 17 ni- 
lai. Nilai yang tidak menjadi acuan yaitu nilai tanggung jawab.

\section{Pengertian Ilmu Pengetahuan Sosial (IPS)}

Barth (1990: 28) mendefinisikan Ilmu Pengetahuan Sosial (IPS) sebagai "Social studies is the interdisciplinary integration of social science and humanities concepts for the purpose of practicing citizenship skills on critical social issues". Dari kutipan tersebut IPS dapat dimaknai sebagai studi terintegrasi dari ilmuilmu sosial dan konsep humaniora, untuk mencapai kompetensi kewarganegaraan yang baik dalam rangka mengkritisi isuisu sosial.

Tasrif (2008: 38) mengemukakan bahwa IPS merupakan kajian ilmu yang berpotensi bagi pengembangan tugastugas pembelajaran yang kaya akan nilai. Tetapi karena sifat ilmunya yang sangat lunak, Nilai-nilai yang terdapat dalam IPS dan humaniora lebih dinamis dan mengandung unsur probabilitas yang cukup banyak.

\section{Hakikat Buku Teks sebagai Media Pembe- lajaran IPS}

Chambiss dan Calfee (Masnur Muslich, 2010: 50) mengungkapkan, buku teks adalah alat bantu siswa untuk memahami dan belajar dari hal-hal yang dibaca dan untuk memahami dunia (di luar dirinya). Buku teks memiliki kekuatan yang luar biasa besar terhadap perubahan otak siswa. Buku teks dapat memengaruhi pengetahuan anak dan Nilai-nilai tertentu.

Menurut Bacon (Swandono dan Edy, 1998: 105), buku teks adalah buku yang digunakan di kelas, disusun dan disiapkan oleh orang yang ahli dalam bidangnya dan dilengkapi dengan saranasarana pengajaran yang sesuai dan serasi. Sarana pengajaran harus disesuaikan dengan jenjang pendidikan siswa sehingga siswa dapat mempelajarinya dengan mudah.

\section{Hakikat Pendidikan Karakter}

Abdullah Munir (2010: 3) mengungkapkan karakter merupakan pola, baik itu pikiran, sikap maupun tindakan yang melekat pada diri seseorang dengan sangat kuat dan sulit dihilangkan. Karakter atau watak juga berarti seperangkat sifatsifat yang selalu dikagumi sebagai tandatanda kebaikan, kebijakan, dan kematangan moral (Darmiyati Zuchdi, 2009: 39). Sementara itu, Pritchard (Suharjana, 2011: 27) mendefinisikan karak ter sebagai sesuatu yang berkaitan dengan kebiasaan individu yang bersifat menetap dan cenderung positif.

Kirschenbaum (1995: 2122) mengungkapkan, secara umum ada lima tujuan pendidikan karakter yakni 1) mengembangkan sikap peduli baik peduli pada diri sendiri, orang lain maupun lingkungan, 2) mengembangkan sikap tanggung jawab dengan bersikap jujur pada diri sendiri maupun orang lain, 3) mengembangkan sikap empati dan toleransi, 4) mengembangkan sikap disiplin dan kerja keras, dan 5) mengembangkan sikap loyal atau kesetiaan dalam pergaulan di masyarakat.

\section{Karakter yang Dikembangkan dalam Pembelajaran di SMP}

Badan Penelitian dan Pengembangan, Pusat Kurikulum Kementerian Pendidikan Nasional (2010: 10) merumuskan materi pendidikan karakter mencakup aspekaspek tabel 1 berikut. 


\section{Materi Pendidikan Karakter Pusat Kurikulum Kemdiknas}

\begin{tabular}{|c|c|c|}
\hline No & Nilai & Deskripsi \\
\hline 1 & Religius & $\begin{array}{l}\text { Sikap dan perilaku yang patuh dalam melaksanakan ajaran agama yang dianutnya, } \\
\text { toleran terhadap pelaksanaan ibadah agama lain dan hidup rukun dengan pemeluk } \\
\text { agama lain. }\end{array}$ \\
\hline 2 & Jujur & $\begin{array}{l}\text { Perilaku yang didasarkan pada upaya menjadikan dirinya sebagai orang yang selalu } \\
\text { dapat dipercaya dalam perkataan, tindakan dan pekerjaan. }\end{array}$ \\
\hline 3 & Toleransi & $\begin{array}{l}\text { Sikap dan tindakan yang menghargai perbedaan agama, suku, etnis, pendapat, sikap } \\
\text { dan tindakan orang lain yang berbeda dari dirinya. }\end{array}$ \\
\hline 4 & Disiplin & $\begin{array}{l}\text { Tindakan yang menunjukkan perilaku tertib dan patuh pada berbagai ketentuan dan } \\
\text { peraturan }\end{array}$ \\
\hline 5 & Kerja keras & $\begin{array}{l}\text { Perilaku yang menunjukkan upaya sungguhsungguh dalam mengatasi berbagai } \\
\text { hambatan belajar dan tugas serta menyelesaikan tugas dengan sebaikbaiknya. }\end{array}$ \\
\hline 6 & Kreatif & $\begin{array}{l}\text { Berpikir dan melakukan sesuatu untuk menghasilkan cara atau hasil baru dari } \\
\text { sesuatu yang telah dimiliki. }\end{array}$ \\
\hline 7 & Mandiri & $\begin{array}{l}\text { Sikap dan perilaku yang tidak mudah tergantung pada orang lain dalam menyelesaikan } \\
\text { tugastugas. }\end{array}$ \\
\hline 8 & Demokratis & $\begin{array}{l}\text { Cara berpikir, bersikap dan bertindak yang menilai sama hak dan kewajiban dirinya } \\
\text { dan orang lain. }\end{array}$ \\
\hline 9 & $\begin{array}{l}\text { Rasa ingin } \\
\text { tahu }\end{array}$ & $\begin{array}{l}\text { Sikap dan tindakan yang selalu berupaya untuk mengetahui lebih mendalam dan } \\
\text { meluas dari sesuatu yang dipelajarinya, dilihat dan didengar. }\end{array}$ \\
\hline 10 & $\begin{array}{l}\text { Semangat } \\
\text { kebangsaan }\end{array}$ & $\begin{array}{l}\text { Cara berpikir, bertindak dan berwawasan yang menempatkan kepentingan bangsa } \\
\text { dan negara di atas kepentingan diri dan kelompoknya. }\end{array}$ \\
\hline 11 & $\begin{array}{l}\text { Cinta tanah } \\
\text { air }\end{array}$ & $\begin{array}{l}\text { Cara berpikir, bersikap dan berbuat yang menunjukkan kesetiaan, kepedulian dan } \\
\text { penghargaan yang tinggi terhadap bahasa, lingkungan fisik, sosial, budaya, ekonomi } \\
\text { dan politik bangsa. }\end{array}$ \\
\hline 12 & $\begin{array}{l}\text { Menghargai } \\
\text { prestasi }\end{array}$ & $\begin{array}{l}\text { Sikap dan tindakan yang mendorong dirinya untuk menghasilkan sesuatu yang } \\
\text { berguna bagi masyarakat dan mengakui serta menghormati keberhasilan orang lain. }\end{array}$ \\
\hline 13 & $\begin{array}{l}\text { Bersahabat/ } \\
\text { komunikatif }\end{array}$ & $\begin{array}{l}\text { Tindakan yang memperlihatkan rasa senang berbicara, bergaul dan bekerjasama } \\
\text { dengan orang lain. }\end{array}$ \\
\hline 14 & Cinta damai & $\begin{array}{l}\text { Sikap, perkataan dan tindakan yang menyebabkan orang lain merasa senang dan } \\
\text { aman atas kehadiran dirinya. }\end{array}$ \\
\hline 15 & $\begin{array}{l}\text { Gemar } \\
\text { membaca }\end{array}$ & $\begin{array}{l}\text { Kebiasaan menyediakan waktu untuk membaca berbagai bacaan yang memberikan } \\
\text { kebajikan bagi dirinya. }\end{array}$ \\
\hline 16 & $\begin{array}{l}\text { Peduli } \\
\text { lingkungan }\end{array}$ & $\begin{array}{l}\text { Sikap dan tindakan yang selalu berupaya mencegah kerusakan pada lingkungan alam } \\
\text { di sekitarnya dan mengembangkan upayaupaya untuk memerbaiki kerusakan alam } \\
\text { yang sudah terjadi. }\end{array}$ \\
\hline 17 & Peduli sosial & $\begin{array}{l}\text { Sikap dan tindakan yang selalu ingin memberi bantuan pada orang lain dan masyarakat } \\
\text { yang membutuhkan. }\end{array}$ \\
\hline 18 & $\begin{array}{l}\text { Tanggung } \\
\text { jawab }\end{array}$ & $\begin{array}{l}\text { Sikap dan perilaku seseorang untuk melaksanakan tugas dan kewajibannya yang } \\
\text { seharusnya ia lakukan terhadap dirinya sendiri, masyarakat, lingkungan (alam, sosial, } \\
\text { budaya), negara dan Tuhan Yang Maha Esa. }\end{array}$ \\
\hline
\end{tabular}

Sumber: Pusat Kurikulum Kementerian Pendidikan Nasional, Bahan Pelatihan Pengembangan Pendidikan Budaya dan Karakter Bangsa (2010: 10). 


\section{Pendekatan Komprehensif}

Pendekatan komprehensif bermakna bahwa pendidikan karakter tersebut menyentuh berbagai aspek kehidupan. Zuchdi (2010: 3637) berpendapat strategi komprehensif dalam penerapan pendidikan karakter tersebut mencakup empat aspek.

Pertama, isi pendidikan nilai harus komprehensif meliputi semua permasalahan yang berkaitan dengan Nilai-nilai yang bersifat pribadi sampai pertanyaanpertanyaan mengenai etika secara umum.

Kedua, metode pendidikan nilai mencakup inkulkasi (penanaman) nilai, pemberian teladan, dan penyiapan generasi muda agar dapat mandiri dengan mengajarkan dan memfasilitasi pembuatan keputusan moral secara bertanggung jawab, dan keterampilanketerampilan hidup yang lain. Pasalnya, keterampilan keterampilan itulah yang akan mengarahkan dan menjadi bekal bagi kehidupan mereka sendiri.

Ketiga, pendidikan nilai hendaknya terjadi dalam keseluruhan proses pendidikan di kelas, dalam kegiatan ekstrakurikuler, dalam proses bimbingan dan penyuluhan, dalam upacara upacara pemberian penghargaan, dan semua aspek kehidupan.

Keempat, pendidikan nilai seharusnya terjadi melalui kehidupan dalam masyarakat. Orang tua, lembaga keagamaan, penegak hukum, polisi, organisasi masyarakat mestinya berpartisipasi dalam pendidikan nilai. $\mathrm{Pa}$ salnya komitmen dan konsistensi dari komponen komponen itulah menjadi cermin dan memengaruhi kualitas moral generasi muda.

Metode dalam pendekatan komprehensif tersebut oleh Kirschenbaum disajikan dalam 100 cara yang dikelompokkan menjadi empat strategi yaitu inkulkasi, teladan, fasilitasi dan pengembangan keterampilan untuk dapat menyesuaikan diri dalam kehidupan.

\section{METODE}

Penelitian ini termasuk penelitian analisis konten inferensial karena berusaha memahami dan memaknai pesan simbolik pada sebuah dokumen. Krippendorff (1981: 21) mengemukakan bahwa "content analysis is a research technique for making replicable and valid inference from data to their context". Analisis konten adalah teknik penelitian untuk membuat inferensi yang valid dan dapat diteliti ulang dari data berdasarkan konteksnya. Darmiyati Zuchdi (1993: 1) me ngatakan dalam analisis konten, penganalisis tidak hanya tertarik pada pesan itu sendiri, tetapi pada pertanyaanpertanyaan yang lebih luas tentang proses dan dampak komunikasi. Definisi tersebut menunjukkan tujuan utama analisis konten haruslah membuat inferensi karena peneliti tidak mungkin memahami dampak komunikasi tanpa membuat infe rensi.

\section{Objek Penelitian}

Dalam analisis konten harus jelas objek/ data yang mana yang dianalisis, bagaimana hal itu didefinisikan dan dari populasi mana data diambil. Oleh karena itu, sumber data penelitian ini adalah buku teks IPS SMP yang digunakan di kelas VII pada semester I yang diterbitkan penerbit nasional. Sesuai perta nyaan penelitian, datanya berupa materi IPS SMP kelas VII pada semester I.

\section{Teknik Analisis Data}

Krippendorff (1981: 52) menyebutkan langkahlangkah dalam analisis konten meliputi pengadaan data, pengurangan atau reduksi data, inferensi dan analisis.

Prosedur analisis konten pada penelitian ini sebagai berikut.

\section{Pengadaan data}

Data pada penelitian ini adalah materi IPS Kelas VII semester 1. Penyajian data dalam penelitian ini dilakukan dengan deskripsi singkat muatan Nilai-nilai karakter yang terdapat dalam tiap tema buku teks beserta strategi pendekatan pendidikan karakter yang dipilih oleh penulis buku teks.

\section{Pengurangan atau reduksi data}

Pengurangan data dimaksudkan untuk mendapatkan hal-hal yang penting sesuai tujuan penelitian serta membuang hal yang tidak relevan. Reduksi data dalam penelitian ini dilakukan melalui diskusi dengan teman sejawat dan ahli. 


\section{Inferensi}

Inferensi menjadi bagian penting dalam analisis konten. Keberhasilan dalam membuat inferensi dipengaruhi oleh pengetahuan tentang konteks data. Darmiyati Zuchdi (1993: 53) mengemukakan dalam melakukan analisis konten inferensial peneliti harus sensitif terhadap konteks data yang diteliti. Hal ini perlu ditunjukkan dengan (1) dalam menganalisis data berusaha agar tidak me ngurangi makna simboliknya (2) menggunakan konstruk analitis yang menggambarkan konteks data. Konstruk analitis ini merupakan gambaran secara operasional tentang pengetahuan peneliti mengenai saling ketergantungan antara data dengan konteks.

\section{Analisis}

Isi komunikasi berupa simbol verba ha nya merupakan bagian dari proses komunikasi. Pasalnya, agar isi komunikasi tersebut dapat memberikan pengaruh pada orang yang diajak komunikasi, juga dipengaruhi bahasa, tipe komunikasi dan alat komunikasi.

\section{HASIL DAN PEMBAHASAN}

SMP di Kota Surakarta berjumlah 97 SMP yang terdiri atas 30 SMP negeri dan 67 SMP swasta. Dalam penelitian ini, informasi buku teks yang dipakai di SMP diperoleh dari Ketua Musyawarah Guru Mata Pelajaran (MGMP) Ilmu Pengetahuan Sosial (IPS) di Kota Surakarta.

Berdasarkan informasi dari MGMP, buku teks utama yang paling banyak digunakan yakni:

\section{buku teks utama yang paling banyak digunakan}

\begin{tabular}{|c|c|}
\hline Judul & : Mari Belajar IPS (Buku Sekolah Elektronik) \\
\hline Penulis & : Muh. Nurdin, S.W. Warsito dan Muh. Nursa'ban \\
\hline Kota dan Penerbit & $\begin{array}{l}\text { : Jakarta, Pusat Perbukuan Depdiknas. Diperbanyak penerbit Eureka } \\
\text { Bookhouse, Jakarta }\end{array}$ \\
\hline Tahun terbit & : 2008 \\
\hline \multicolumn{2}{|c|}{ Sementara itu buku pendamping yang paling banyak digunakan yaitu } \\
\hline Judul & : IPS Terpadu 1 \\
\hline Penulis & : Drs. Anwar Kurnia \\
\hline Kota dan penerbit & : Jakarta, Yudhistira \\
\hline Tahun terbit & : 2007 \\
\hline \multicolumn{2}{|c|}{ Selanjutnya, penyebutan buku ini menggunakan nama penerbitnya, Yudhistira. } \\
\hline Judul & : IPS TERPADU $1 \mathrm{~A}$ \\
\hline Penulis & $\begin{array}{l}\text { : Tim Abdi Guru yang terdiri atasDrs. Hasan Budi Sulistyo dan Bam- } \\
\text { bang Suprobo, M.Pd }\end{array}$ \\
\hline Kota dan penerbit & : Jakarta, Erlangga \\
\hline Tahun terbit & : 2007 \\
\hline \multicolumn{2}{|c|}{ Selanjutnya, penyebutan buku ini menggunakan nama penerbitnya, Erlangga. } \\
\hline
\end{tabular}

Analisis data muatan pendidikan karakter dalam buku teks IPS SMP di Kota Surakarta secara umum dengan menggunakan program SPSS versi 16.0 menunjukkan bahwa mean muatan pendidikan karakter pada semua buku teks sebesar 34,45 dengan median sebesar 34,00, dan modus sebesar 36,00. Muatan pendidikan karakter dalam buku teks IPS SMP terendah sebesar 65,60 dan tertinggi sebesar 126,33. 
Kegiatan analisis data dalam penelitian ini dilakukan melalui dua langkah berikut

\section{Penelaahan secara deskriptif}

Analisis maksud atau akibat komunikasi. Pada tahap ini pesan komunikasi dalam buku teks dianalisis berdasarkan teori pendekatan pendidikan karakter dengan pedoman analisis.

Sementara itu, penelaahan deskriptif pada penelitian ini dilakukan secara kuantitatif (quantitative evaluation) seperti pendapat Powell (2006, p. 110). Oleh sebab itu, peneliti menggunakan pedoman analisis dengan skala rating yang mencakup aspek, subaspek, indikator dan kriteria penilaian. Dari tiaptiap item indikator tersebut dibuat skala rating dengan skala :

$$
\begin{aligned}
& 3=\text { memadai } \\
& 2=\text { cukup memadai } \\
& 1=\text { kurang memadai } \\
& 0=\text { tidak memadai }
\end{aligned}
$$

Kriteria kecukupan penilaian seperti tercantum pada tabel berikut.

\section{Kriteria Kecukupan Penilaian Muatan Pendidikan Karakter pada Buku Teks IPS SMP di Kota Surakarta}

\begin{tabular}{ccc}
\hline No & Interval & Kategori \\
\hline 1 & $>\mathrm{Mi}+1,5 \mathrm{SBi}$ & Memadai \\
2 & Mi s.d. $\mathrm{Mi}+1,5 \mathrm{SBi}$ & Cukup Memadai \\
3 & $\mathrm{Mi}-1,5 \mathrm{SBi}$.d. Mi & Kurang Memadai \\
4 & $<$ Mi $1,5 \mathrm{SBi}$ & Tidak Memadai \\
\hline
\end{tabular}

Interval kriteria penilaian didasarkan pada skor tertinggi dan skor terendah pada tiaptiap aspek muatan pendidikan karakter. Selanjutnya, skor rerata ideal (Mi) dan skor simpangan baku ideal (SBi) dihitung dengan menggunakan formula sebagai berikut.

$\mathrm{Mi}=1 / 2($ skor tertinggi + skor terendah)

$\mathrm{SBi}=1 / 6$ (skor tertinggi - skor terendah)

Berdasarkan rumusan di atas, diperoleh kriteria penilaian muatan pendidikan karakter pada tabel berikut.

\section{Kriteria Penilaian Muatan Pendidikan Karakter dalam Buku Teks IPS SMP di Kota Surakarta}

\begin{tabular}{ccc}
\hline No & Interval & Kategori \\
\hline 1 & $>216$ & Memadai \\
2 & 144216 & Cukup Memadai \\
3 & $72-143,99$ & Kurang Memadai \\
4 & $<72$ & Tidak Memadai \\
\hline
\end{tabular}

Berdasarkan kategori penilaian tersebut, persentase muatan pendidikan karakter pada semua aspek (aspek nilai dan as- pek pendekatan komprehensif) distribusi frekuensinya sebagai berikut. 


\section{Distribusi Frekuensi Semua Aspek Muatan Pendidikan Karakter}

\begin{tabular}{|c|c|c|c|c|}
\hline No & Interval & Kategori & Frekuensi & Frekuensi Relatif (\%) \\
\hline 1 & $>216$ & Memadai & 0 & 0 \\
\hline 2 & 144216 & Cukup Memadai & 0 & 0 \\
\hline 3 & $72-143,99$ & Kurang Memadai & 6 & 46,00 \\
\hline 4 & $<72$ & Tidak Memadai & 7 & 54,00 \\
\hline \multicolumn{3}{|c|}{ Jumlah } & 13 & 100,00 \\
\hline
\end{tabular}

Berdasarkan tabel di atas, muatan pendidikan karakter dalam buku teks kurang memadai (sebanyak 46\%) dan tidak memadai (sebanyak 54\%). Pada penelitian ini, tidak ada buku teks yang memadai atau cukup memadai muatan pendidikan karakternya, dilihat dari peta nilai untuk siswa SMP berdasarkan bahan pengembangan pendidikan budaya dan karakter bangsa Pusat Kurikulum dan pendekatan komprehensif.

Sementara itu, aspek Nilai-nilai karakter (dari skor tertinggi ideal sebesar 177) yang tertinggi terdapat dalam buku 2: Yudhistira dengan rerata sebesar 75,67 atau 42,75\% (kurang memadai), kemudian dalam buku 3: Erlangga dengan rerata sebesar 47,86 atau $27,03 \%$ (kurang memadai), dan yang terendah terdapat dalam buku 1: Pusat Perbukuan dengan rerata sebesar 41,38 atau 23,37\%. Secara keseluruhan rerata aspek Nilai-nilai karakter pada ketiga buku sebesar 54,97 atau $31,05 \%$. Aspek pendekatan komprehensif (dari skor tertinggi ideal 111) yang tertinggi terdapat pada buku 2: Yudhistira dengan rerata sebesar 50,67 atau 45,64\% (kurang memadai), pada buku 3: Erlangga rerata sebesar 31,32 atau 28,21\% (kurang memadai), dan terendah pada buku 1: Pusat Perbukuan dengan rerata 24,34 atau 21,92\% (tidak memadai). Secara keseluruhan rerata aspek pendekatan pendidikan karakter komprehensif pada ketiga buku sebesar 35,44 atau $31,92 \%$.

\section{Nilai-nilai Karakter yang Terintegrasi dalam Buku Teks}

Secara keseluruhan, sebanyak tiga buku teks yang dianalisis sudah mengintegrasi- kan Nilai-nilai karakter. Nilai-nilai karakter tersebut diintegrasikan secara eksplisit dan implisit. Nilai-nilai karakter yang terintegrasi dan yang belum terintegrasi pada buku teks sebagai berikut.

\section{Cara Pengintegrasian Nilai-nilai Karakter}

Buku-buku yang dianalisis tidak secara tegas menyebutkan cara pengintegrasian Nilainilai karakter yang mengacu pada pendekatan pendidikan karakter komprehensif. Akan tetapi, setelah dianalisis ketiga buku secara tidak langsung sudah menerapkan pendekatan pendidikan karakter komprehensif yang mencakup inkulkasi/penanaman nilai, keteladanan nilai, fasilitasi nilai dan pengembangan keterampilan akademik dan sosial.

\section{Pembahasan}

Buku IPS yang digunakan di SMP Kota Surakarta bervariasi. Buku-buku yang digunakan baik buku acuan utama maupun buku pendamping, keseluruhannya berbasis KTSP. Berdasarkan informasi dari MGMP IPS SMP Kota Surakarta, buku utama yang paling banyak digunakan berjudul Mari Belajar IPS 1 untuk SMP/MTs kelas VII. Sedangkan buku pendamping yang paling banyak dipakai yaitu IPS Terpadu 1, SMP/MTs Kelas VII dan IPS Terpadu untuk SMP Kelas VII jilid 1 A. Ada dua alasan utama penggunaan Bukubuku tersebut.

Pertama, buku utama berjudul Mari Belajar IPS 1 untuk SMP/MTs kelas VII digunakan karena buku tersebut termasuk buku berkategori Buku Sekolah Elektronik (BSE). BSE merupakan buku yang secara resmi disarankan oleh pemerintah. Buku BSE tersebut juga tersedia di perpustakaan 
sekolah. Buku BSE juga mudah didapatkan di Kota Surakarta. Ditilik dari sisi harga, buku BSE relatif lebih murah dibandingkan dengan buku dari penerbit lain.

Kedua, buku pendamping berjudul IPS Terpadu 1, SMP/MTs Kelas VII IPS dan Terpadu untuk SMP Kelas VII jilid 1A banyak dipilih karena materi maupun penyajian yang terdapat dalam kedua buku tersebut bisa melengkapi buku utama. Meskipun dari sisi harga kedua buku tersebut lebih mahal diban dingkan BSE, kedua buku tersebut juga mudah didapatkan di Kota Surakarta.

Berdasarkan deskripsi data muatan pendidikan karakter pada uraian sebelumnya, muatan pendidikan karakter yang terdapat dalam buku teks IPS SMP di Kota Surakarta pada setiap buku berbeda-beda. Muatan pendidikan karakter yang terdiri atas aspek nilai dan pendekatan pendidikan karakter dapat dikelompokkan pada tiap buku teks seperti tabel berikut.

\section{Nilai-nilai Karakter yang Terintegrasi dalam Buku Teks IPS}

\begin{tabular}{|c|c|c|c|}
\hline No & Buku & Nilai-nilai Terintegrasi & $\begin{array}{l}\text { Nilai-nilai yang } \\
\text { Belum Terintegrasi }\end{array}$ \\
\hline 1 & $\begin{array}{l}\text { Buku 1: Mari Belajar } \\
\text { IPS untuk SMP/MTs } \\
\text { kelas VII (Penerbit Pusat } \\
\text { Perbukuan) }\end{array}$ & $\begin{array}{l}\text { Religius,jujur, toleransi, disiplin, kerja keras, } \\
\text { kreatif, mandiri, demokratis, rasa ingin tahu, } \\
\text { cinta tanah air, menghargai prestasi, bersahabat/ } \\
\text { komunikatif, cinta damai, gemar membaca, } \\
\text { peduli sosial, peduli lingkungan dan hemat. }\end{array}$ & $\begin{array}{l}\text { Semangat } \\
\text { kebangsaan }\end{array}$ \\
\hline 2 & $\begin{array}{l}\text { Buku 2: IPS Terpadu 1, } \\
\text { SMP/MTs Kelas VII IPS } \\
\text { (Penerbit Yudhistira) }\end{array}$ & $\begin{array}{l}\text { Religius, jujur, toleransi, disiplin, kerja keras, } \\
\text { kreatif, mandiri, demokratis, rasa ingin tahu, } \\
\text { cinta tanah air, menghargai prestasi, bersahabat/ } \\
\text { komunikatif, cinta damai, gemar membaca, } \\
\text { peduli sosial, peduli lingkungan dan hemat }\end{array}$ & $\begin{array}{l}\text { Semangat } \\
\text { kebangsaan }\end{array}$ \\
\hline 3 & $\begin{array}{l}\text { Buku 3: Terpadu untuk } \\
\text { SMP Kelas VII jilid } 1 \text { A } \\
\text { (Penerbit Erlangga) }\end{array}$ & $\begin{array}{l}\text { Religius, jujur, toleransi, disiplin, kerja keras, } \\
\text { kreatif, mandiri, demokratis, rasa ingin tahu, } \\
\text { cinta tanah air, menghargai prestasi, bersahabat/ } \\
\text { komunikatif, cinta damai, gemar membaca, } \\
\text { peduli sosial, peduli lingkungan dan hemat. }\end{array}$ & $\begin{array}{l}\text { Semangat } \\
\text { kebangsaan }\end{array}$ \\
\hline
\end{tabular}

\section{Daftar Muatan Pendidikan Karakter yang Tersaji dalam Buku Teks IPS di Kota Surakarta}

\begin{tabular}{clll}
\hline No & \multicolumn{1}{c}{ Buku } & \multicolumn{1}{c}{ Aspek Nilai } & \multicolumn{1}{c}{$\begin{array}{c}\text { Aspek Pendekatan } \\
\text { Komprehensif }\end{array}$} \\
\hline 1 & Buku 1: Mari Belajar & Religius,jujur, toleransi, disiplin, & Inkulkasi/penanaman nilai, \\
& IPS untuk SMP/MTs & kerja keras, kreatif, mandiri, & keteladanan nilai, fasilitasi \\
& kelas VII (Penerbit & nemokratis, rasa ingin tahu, cinta & nilai, dan pengembangan \\
& Pusat Perbukuan) & tanah air, menghargai prestasi, & keterampilan akademik dan \\
& & $\begin{array}{l}\text { bersahabat/komunikatif, cinta damai, } \\
\text { gemar membaca, peduli sosial, peduli }\end{array}$ \\
& lingkungan dan hemat.
\end{tabular}


2 Buku 2: IPS Terpadu 1, Religius, jujur, toleransi, disiplin, kerja Inkulkasi/penenaman nilai, SMP/MTs Kelas VII IPS keras, kreatif, mandiri, demokratis, keteladanan nilai, fasilitasi (Penerbit Yudhistira) rasa ingin tahu, cinta tanah air, menghargai prestasi, bersahabat/ komunikatif, cinta damai, gemar nilai, dan pengembangan keterampilan akademik dan membaca, peduli sosial, peduli sosial lingkungan dan hemat

3 Buku 3: Terpadu untuk SMP Kelas VII jilid 1 A (Penerbit Erlangga)
Religius, jujur, toleransi, disiplin, kerja Inkulkasi/penenaman nilai, keras, kreatif, mandiri, demokratis, keteladanan nilai, fasilitasi rasa ingin tahu, semangat kebangsaan, nilai, dan pengembangan cinta tanah air, menghargai prestasi, keterampilan akademik dan bersahabat/komunikatif, cinta damai, sosial gemar membaca, peduli sosial, peduli lingkungan dan hemat.

\section{Kesesuaian Nilai Nilai Karakter pada Buku Teks IPS SMP dengan Peta Konsep Nilai}

Sesuai peta konsep nilai dalam bahan pelatihan pengembangan pendidikan dan karakter bangsa, peta nilai karakter untuk siswa SMP sebanyak 17 nilai karakter. Nilai karakter tersebut bisa diintegrasikan dengan pokok bahasan baik secara eksplisit maupun implisit. Secara keseluruhan pada aspek nilai urutannya adalah buku 2: Yudhistira dengan kategori kurang memadai, buku 3: Erlangga dengan kategori kurang memadai, dan buku 1: Pusat Perbukuan dengan kategori tidak memadai.

\section{Kesesuaian Pendekatan Pendidikan Kara- kter dengan Pendekatan Komprehensif}

Model pendekatan komprehensif yang dipopulerkan Kirschenbaum oleh para ahli pendidikan dinilai sebagai model pendekatan pendidikan karakter yang diharapkan dapat memberikan solusi masalah secara relatif lebih tuntas. Aspek pendekatan pendidikan karakter dalam buku teks berkaitan dengan pendekatan pendidikan karakter yang dipilih penulis buku teks untuk mengintegrasikan Nilai-nilai pada materi/pokok bahasan. Secara keseluruhan aspek pendekatan komprehensif urutannya adalah buku 2: Yudhistira dan buku 3: Erlangga dalam kategori kurang memadai dengan rerata 50,67 dan 31,32 sedangkan buku 1: Pusat Perbukuan dalam ka tegori tidak memadai dengan rataan 24,34.

\section{SIMPULAN}

Berdasarkan hasil analisis konten dan pembahasan hasil penelitian dapat di simpulkan hal-hal berikut.

Nilai-nilai karakter yang lebih sering diintegrasikan pada masingmasing buku berbeda beda. Nilai-nilai karakter yang lebih sering diintegrasikan pada buku Mari Belajar IPS 1 terbitan Pusat Perbukuan yaitu: kreatif, mandiri dan rasa ingin tahu, buku IPS Terpa$d u 1$ terbitan Yudhistira yaitu: religius, kerja keras, kreatif, mandiri, bersahabat dan peduli sosial dan buku IPS Terpadu $1 A$ terbitan Erlangga yaitu: kreatif, mandiri dan rasa ingin tahu.

Cara pengintegrasian Nilai-nilai karakter melalui empat metode dalam pendekatan komprehensif yang mencakup inkulkasi nilai, keteladanan nilai, fasilitasi nilai dan pengembangan keterampilan akademik dan sosial. Akan tetapi, metode dalam pendekatan komprehensif yang paling sering digunakan yaitu pengembangan keterampilan akademik dan sosial.

Kesesuaian antara Nilai-nilai karakter dalam buku teks dengan peta nilai untuk siswa SMP dalam bahan pelatihan pengembangan pendidikan dan karakter bangsa Pusat Kurikulum Kemdiknas yang disajikan buku teks IPS secara keseluruhan kurang memadai dengan rerata 54,97 (dari skor tertinggi ideal sebesar 177) atau 31,05\%.

Kesesuaian antara pendekatan pendidi- 
kan karakter dengan pendekatan pendidikan karakter komprehensif yang disajikan buku teks IPS secara keseluruhan kurang memadai dengan rerata 35,44 (dari skor tertinggi ideal 111) atau 31,92\%.

Berdasarkan simpulan dapat diajukan saran sebagai berikut.

Guru sering memanfaatkan buku teks sebagai media pembelajaran utama dalam pembelajaran. Oleh sebab itu, guru perlu mempertimbangkan kualitas buku teks yang akan digunakan, tidak hanya berdasarkan pokok bahasan/tema tetapi juga muatan pendidikan karakter yang terintegrasi dalam buku teks.

Untuk menunjang penerapan pendidikan karakter dalam pembelajaran, sebuah buku teks tidak harus digunakan secara keseluruhan. Guru dapat menggunakan sebagian isi buku atau menggunakan lebih dari satu buku teks dengan cara memadukan materi/ tema yang relevan. Guru juga dapat menambah dengan materi lain yang relevan dari luar buku teks seperti dari media cetak maupun internet. Oleh karena itu, guru perlu memperkaya wawasan dengan mencari sumber materi selain dari buku teks.

Buku-buku teks IPS terbaru seharusnya mengintegrasikan Nilai-nilai karakter yang direkomendasikan oleh Pusat Kurikulum dan menerapkan pendekatan pendidikan karakter komprehensif dengan tanpa mengurangi substansi/isi materi sesuai SK/KD.

Perlu ada penelitian lanjutan untuk menelisik penerapan pendidikan karakter dalam pembelajaran IPS ditilik dari penyajian pembelajaran di kelas.

\section{UCAPAN TERIMA KASIH}

Dalam penulisan artikel jurnal ini, penulis sangat dibantu oleh banyak pihak khususnya dosen pembimbing. Untuk itu, dalam kesempatan ini penulis menyampaikan terima kasih kepada yang terhormat Pembimbing tesis, yang telah banyak membantu, mengarahkan dan membimbing sehingga artikel jurnal ini dapat terselesaikan.

\section{DAFTAR PUSTAKA}

Barth, James L. 1990. Methode of Instructional in Social Study Education. Lanham: University of America.

Kirschenbaum, Howard. 1995. 100 Ways to Enchance Values and Morality in Schools And Youth Setting. Boston: Allyn and Bacon.

Krippendoff, Klaus. 1981. Content Analysis: An Introduction to Its Methodology. London: Sage Publication.

Munir, Abdullah. 2010. Pendidikan Karakter: Membangun Karakter Anak Sejak Dari Rumah. Yogyakarta: PT Pustaka Insan Madani.

Muslich, Masnur. 2010. Text Book Writing. Yogyakarta: A Ruzz Media.

Powel, R.R. 2006. Evaluation Research: An Overview.Library Trend; Summer 2006; 55, 1; ProQuest Education Journals; page 102120. Diambil pada 12 Desember 2011 dari SrchMode $=1 \&$ sid $=1 \&$ Fmt $=6 \&$ VInst $=$ PROD\&VType $=$ PQD\&RQT $=309 \& V N a m e=$ $P Q D \& T S=1236051551 \&$ clientId $=68516$

Pusat Kurikulum. 2010. Bahan Pelatihan: Pengembangan Pendidikan dan Karakter Bangsa. Jakarta: Pusat Kurikulum Kemdiknas

Suharjana. 2011. Model Pengembangan Karakter Melalui Pendidikan Jasmani dan Olahraga. Pendidikan Karakter Dalam Perspektif Teori dan Praktik. Yogyakarta: UNY Press.

Swandono, dan Edy Suryanto. 1998. Telaah Kurikulum dan Telaah Buku Teks. Surakarta: UNS Press.

Tasrif. 2008. Pengantar Pendidikan Ilmu So sial. Yogyakarta: Genta Press.

Zuchdi, Darmiyati. 1993. Panduan Penelitian Analisis Konten. Yogyakarta: Lembaga Penelitian IKIP Yogyakarta.

. 2010. Humanisasi Pendidikan: Menemukan Kembali Pendidikan Yang Manusiawi. Jakarta: Bumi Aksara.

Zuchdi, Darmiyati, dkk. 2009. Pendidikan Karakter: Grand Design dan Nilai-nilai Target. Yogyakarta: UNY Press. 